\title{
A FENNTARTHATÓSÁGRA NEVELÉS JEGYÉBEN MEGVALÓSULÓ SZAKMAI GYAKORLAT AZ ELTE TÓK-ON
}

\section{Hill Katalin - Bauer Zita}

ELTE Tanító- és Óvóképző Kar, Természettudományi Tanszék

\section{Bevezetés}

A fenntarthatóság elveinek a pedagógiai munkába való beépülése elengedhetetlen feltétele annak, hogy a lehető legkorábbi életszakaszban elkezdődjön a felnövekvő gyermekek környezettudatos életmódjának alakítása, és a környezettel harmóniában élő nemzedék szemléletének alakítása (vö. Cade és Bowden, 2011; Vida, 2001).

Ebben kulcsfontosságú szerepe van a pedagógusképző intézményeknek, azok részeinek, tanszékeinek, így az ELTE Tanító- és Óvóképző Kar Természettudományi Tanszékének is. Intézményünkben a fenntarthatóságra nevelés terén kiemelt célként jelenik meg egyrészt a hallgatók saját környezetharmonikus életmódjának folyamatos alakítása, másrészt a 3-12 éves gyermekek környezettudatos magatartásának formálásához szükséges kompetenciák megalapozása, fejlesztése.

A fenntarthatóságra nevelés céljai, törekvései (vö. Cade és Bowden, 2011; Vida, 2001; Vásárhelyi, 2010), valamint elmélete és gyakorlati megvalósításának lehetőségei megjelennek képzési dokumentumainkban, kurzusainkban egyaránt. Tisztában vagyunk azzal, hogy leendő pedagógusok számára nekünk kell megteremtenünk azokat az alapokat, melyek segítségével a későbbi pedagógiai munkájuk során hatékonyan dolgozhatnak.

Hisszük, hogy mind az egyén (hallgató) fenntartható szemléletmódjának és attitüdjének formálásában, mind a kialakult szemlélet kisdiákoknak történő továbbadásához szükséges módszertani repertoár bővülésében kardinális szerepe van a tantermen kívüli oktatásnak, illetve az élményekkel társuló személyes tapasztalatszerzésnek (vö. Lohri és Schwyter, 2004). Ennek elősegítése céljából a természetismeret müveltségi területet végző hallgatóink számára (ők 5 . és 6 . osztályban is taníthatják majd a természetismeret tantárgyat) elindítottuk az ún. önkéntes szakmai gyakorlatot. Ennek lényege, hogy a hallgatók szabadon választanak egy intézményt, melyet három féléven keresztül (a nyolc féléves tanítóképzés 3-5. félévében) látogatnak, és aktívan bekapcsolódnak annak fenntarthatóságra nevelési gyakorlatába.

A választható helyszíneket két fő csoportra oszthatjuk. Az első csoportba Karunktól független intézmények tartoznak, azonban kivétel nélkül mindegyikben a fenntartható életmódot szolgáló oktatási-nevelési folyamat is zajlik. A választható intézmények a következők: két ökoiskola (Németvölgyi Általános Iskola, és 1. sz. Általános Iskola, Budaörs), Magyar Természettudományi 
Múzeum, Sas-hegyi Természetvédelmi Terület, ELTE TTK Ásványtani Tanszék, Szemlö-hegyi-barlang, Pangea Egyesület, Vakok Állami Intézete.

A másik csoport két Európai Unió által támogatott nemzetközi projektet foglal magába, melyeknek magvalósításához az ELTE Gyakorló Általános Iskola nyújt otthont. Az egyik az ún. Beagle projekt (lásd Beagle projekt oldala; illetve Vastagné és mtsai., 2011; Füzné, 2012, 2013), a másik pedig a CarbonDetectives projekt (Carbon Detectives projekt oldala; illetve www.carbondetectives. $h u$ ).

A három félév alatt a hallgatók egyre önállóbban dolgoznak. A gyakorlat első félévében a választott intézmény programjának, az ott zajló munkának a megfigyelése, megismerése, illetve feladatok felügyelet mellett történő elvégzése zajlik. A második félévben már önállóan dolgozhatnak, például programokat állítanak össze és hajtanak végre gyermekcsoportokkal. E félév végén beszámolnak tapasztalataikról. A harmadik félévben már a következő évfolyamból érkező hallgatóknak is segítenek, mentorálják őket.

A munka 2011 tavaszán indult, tanító szakos, természetismeret müveltségterületet végző hallgatók körében, tehát a 2014 tavaszán a negyedik ciklust kezdjük meg.

A továbbiakban a lehetőségek közül két a nemzetközi projektet, illetve emellett néhány egyéb gyakorlati helyszínt mutatunk be.

\section{Nemzetközi projektek}

Az ELTE TÓK bekapcsolódott két, a fenntarthatóságra nevelés megvalósítását elősegítő Európai Unió által támogatott nemzetközi projektbe. Magyarországon mindkét program a Magyar Környezeti Nevelési Egyesület (lásd Beagle projekt oldala; Carbon Detectives projekt oldala; www.carbondetectives.hu, illetve Füzné, 2012, 2013; Vastagné és mtsai., 2011) támogatásával valósult meg. Az egyesület segítségével kapcsolódhattak a programokhoz a magyarországi iskolák, ezen felül lehetőséget biztosított a pedagógusok számára továbbképzéseken, tapasztalatcserén, a diákok számára pedig versenyeken való részvételre.

A CarbonDetectives projekt 2009-ben indult az EU által támogatott mintegy 400 nemzetközi, ún. Intelligens Energia projekt egyikeként. A programhoz öt Európai ország (Ausztria, Bulgária, Csehország, Egyesült Királyság, Magyarország) csatlakozott, melyek mindegyike támogat egy másik, nem partner európai országot.

A Beagle projektet (Biodiversity Education and Awareness to Grow a Living Environment, magyar nyelvre fordítva Biodiverzitás-oktatás és tudatosság az élö környezetért) az EU „Egész életen át tartó tanulás” programjának COMENIUS alapprogramja támogatja és finanszírozza, melyhez Anglia, Magyarország, Lengyelország, Németország, Norvégia és Szlovákia csatlakozott. A következő táblázat a két program céljait foglalja össze röviden. 
A nemzetközi projektek főbb céljai

\begin{tabular}{|c|c|}
\hline CarbonDetectives projekt & Beagle projekt \\
\hline \multicolumn{2}{|c|}{ Európa országainak integrálása a fenntarthatóságra nevelés szempontjából } \\
\hline \multicolumn{2}{|c|}{$\begin{array}{l}\text { környezettudatos attitüd és fenntarthatóbb életstratégia széleskörü formálása (tanítók, } \\
\text { tanárok, diákok, szülök, egyetemi hallgatók és oktatók körében) }\end{array}$} \\
\hline \multicolumn{2}{|c|}{$\begin{array}{l}\text { a pedagógusok tudásának, ismereteinek bővítése, környezettudatos szemléletük fejlesztése, a } \\
\text { fenntarthatóságra neveléssel kapcsolatos módszertani repertoárjának bővitése }\end{array}$} \\
\hline \multicolumn{2}{|c|}{ természettudományos megfigyelések, mérések kisérletek végzése, közvetlen tapasztalatszerzés } \\
\hline tevékenységközpontú tantermi oktatás & $\begin{array}{l}\text { a tantermen kívüli oktatás színvonalának } \\
\text { emelése }\end{array}$ \\
\hline az energiatudatosság növelése & $\begin{array}{l}\text { a biodiverzitás fenntartható életmóddal és } \\
\text { klímaváltozással történő összefüggésének } \\
\text { kiemelése }\end{array}$ \\
\hline $\begin{array}{l}\text { az európai iskolák } \mathrm{CO}_{2} \text {-lábnyomának - így } \\
\text { klímaváltoztató hatásának - becslése és } \\
\text { csökkentése }\end{array}$ & a fák nemzetközi monitorozása \\
\hline
\end{tabular}

\section{A projektek megvalósítása}

A programokban karunk természetismeret müveltségterületet végző hallgatói, a Természettudományi Tanszék oktatói, az ELTE Gyakorló Általános Iskola diákjai (8-14 éves korig), tanárai és tanítói vettek részt, ezáltal igen széleskörü szemléletformálásra nyílt lehetőség.

\section{A CarbonDetectives projekt}

A program hat témakör - Éghajlat és időjárás, Éghajlatváltozás, Energia, Energiatakarékosság, Közlekedés, és Táplálkozás - köré csoportosul. A projekt honlapján, mely minden ország saját nyelvén elérhető (lásd www.carbondetectives.hu) valamennyi témához segédanyag található (útmutató, ötletgyüjtemény, kérdőívek), két különböző korosztály, a 8-11, illetve a 11-14 évesek számára.

A programot projektmódszer segítségével, negyedik osztályos tanulókkal kezdtük, és három féléven át (így 5. osztályba átnyúlóan) folytattuk. A környezetismeret órák keretében hetente, vagy kéthetente iktattunk be egy-egy nyomozó órát.

Az órák között eltelt idő lehetővé tette a szülőkkel együtt történő megfigyeléseket is, például egy-egy időjárási elem megfigyelését, rögzítését, vagy a közösen megvásárolt élelmiszerek származási helyének folyamatos ellenőrzését. A szülők bevonására nagy hangsúlyt fektettünk, hiszen az ő környezettudatos szemléletformálásuk a gyermekeiken keresztül különös jelentőségü és hatékonyságú.

A ,nyomozó órákat” csoportmunkában, ötfős, állandó összetételü csoportok létrehozásával valósítottuk meg, mert úgy gondoltuk, ebben a munkaformában 
valósítható meg leghatékonyabban a tervezett munka, illetve érvényesülhetnek a gyermekek egyéni ambíciói. Az órákon szerepet kapott a rövidebb és hosszabb távú megfigyelés, mérés, tanulói és tanári kísérlet, emellett a tanórán kívül is végeztek megfigyeléseket és gyüjtőmunkát a gyermekek.

Jelen tanulmány terjedelmében nincs mód valamennyi óra és kísérlet részletes bemutatására, ezért csupán egy olyan tevékenységet vázolunk fel, melyen jól látszik, hogy az egyes témakörök mennyire összefüggenek egymással (például közlekedés során az üzemanyagból keletkező anyagok és éghajlatváltozás kapcsolata). Ezekre rávilágítva a program jó lehetőséget nyújt az ok-okozati összefüggések felfedezésére, a rendszerszemléletü gondolkodás fejlesztésére.

\section{Élelmiszerek származási helyének meghatározása}

A munka előzményeként a diákok egy héten keresztül élelmiszerek csomagolóanyagokat gyüjtöttek otthonukban. A nyomozó óra alkalmával megkeresték a termék származási helyét, melyet térképen jelöltek. Ezt követően, hallgatóink segítségével meghatározták, „mennyit utazott” a termék, míg a bolt polcaira került, majd az áru által megtett kilométerekből megbecsülték a szükséges üzemanyag mennyiségét és ennek költségét.

Az eredmények tükrében a gyerekek közösen vonták le a termékek utazásának következményeivel kapcsolatos következtetéseket:

- minél távolabbról érkezik a termék, annál több üzemanyag, így energia felhasználásával jár;

- minél távolabbról érkezik a termék, annál több szén-dioxid kerül légkörünkbe, ami az éghajlatváltozást - globális felmelegedést - elösegíti (az üvegházhatás egy korábbi alkalmon értelmezésre és modellezésre került);

- a szén-dioxid mellett számos egyéb környezetszennyező anyag jut a levegőbe;

- azonos kategóriájú termékek (pl. tejtermékek, vagy pékáruk) esetén, összehasonlítva a kapott eredményeket, megállapítható, hogy melyik termék vásárlása a leginkább környezet- és költségkímélő;

- felelösségünk törekedni arra, hogy adott terméket a lehetséges legközelebbi helyről szerezzük be.

A bemutatott példa csak egyetlen a program során elvégzett számos tevékenység közül. Reményeink szerint a CarbonDetectives projektben való részvétel lehetőséget nyújtott az energiatudatosság növelésére és a fenntartható életstratégia fejlesztésére a tanárokban és a diákokban egyaránt.

\section{Beagle projekt}

A projekt lényege a fák nemzetközi monitorozása. A diákok feladata a kiválasztott fa életmüködésének, fenológiai változásának egész évben történő megfigyelése. A megfigyelések időpontjainak és eredményeinek rögzítése a program honlapján (http://mkne.hu/projektek.php?projekt=10) történik (lásd 1. ábra), majd 
valamennyi európai iskola által beküldött adat az angliai központban kerül feldolgozásra. A gyerekek így nemzetközi kutatásban is részt vesznek, megfigyeléseik a tudomány számára is hasznos konkrét adatokat eredményeznek. A kutatási eredmények lehetővé teszik, hogy megvizsgáljuk, változnak-e, és ha igen, hogyan az egyes fák fenofázisainak időpontjai Európa-szerte, illetve a tapasztalt változások összefüggésbe hozhatóak-e a klimatikus változásokkal.

A résztvevő osztályok hat fafaj közül választhattak, melyek közül iskolánkban célszerüen az udvaron található közönséges nyirre esett a választás.

A programot környezetismeret órák müvelődési tartalmába illesztettük be. Tantermi óra keretében felmértük a diákok előzetes elképzeléseit és ismereteit a fákkal kapcsolatban, valamint előkészítettük a terepi munkát. A megfigyeléseket minden fenofázisban elvégeztük, így a fa életében bekövetkező valamennyi jelentős változást nyomon követhettük. Elsőként kissé távolabbról a fa egészét, és fő részeit figyelték meg, illetve azonosították a diákok. Közelebbről valamennyi érzékelhető tulajdonságát megfigyelték (például a törzs színe, felületének tapintása stb.), élőlényeket és életnyomokat kerestek rajta, majd tapasztalataikat feladatlapon rögzítették.

Méréseket is végeztek, például a fa törzsének méretét elöször tenyerük, majd mérőszalag segítségével határozták meg.

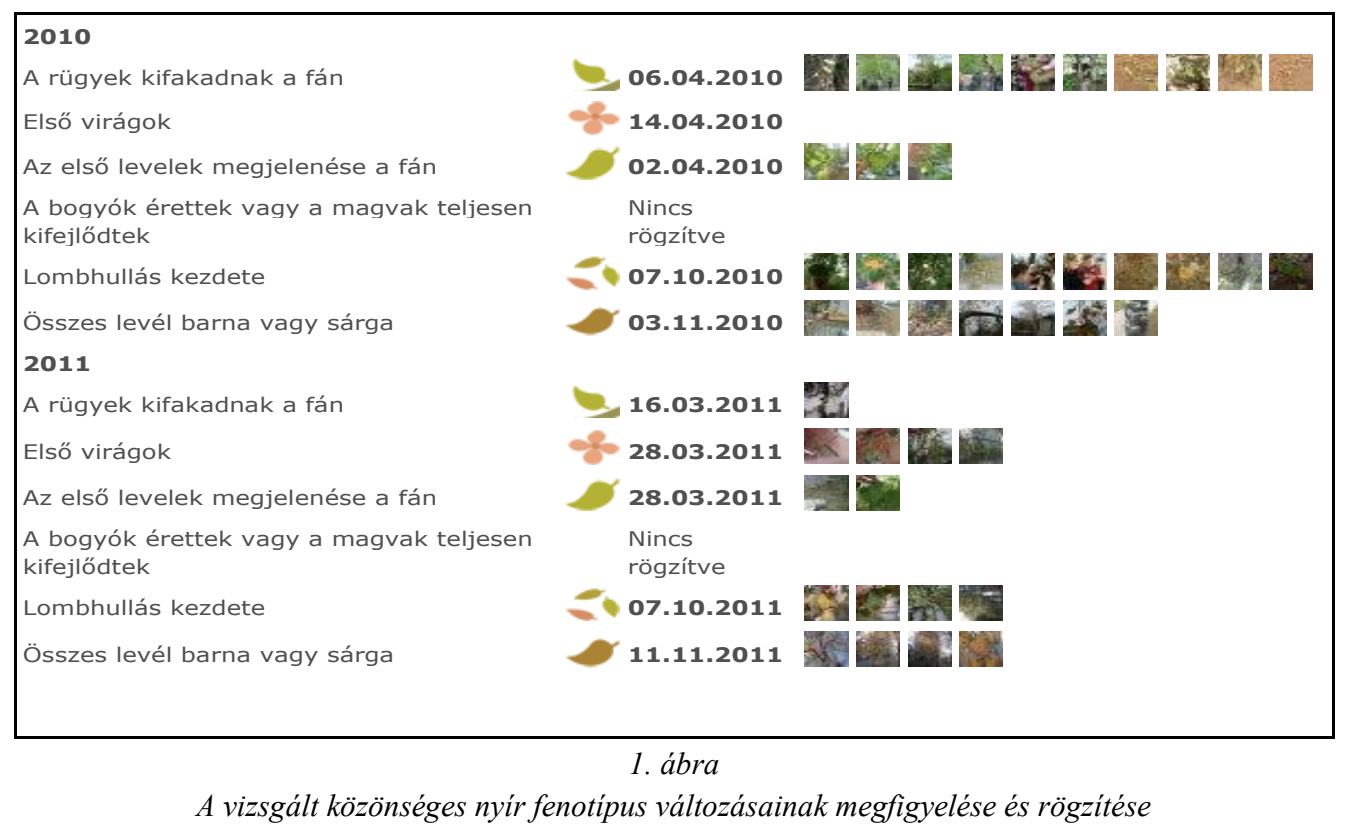

A program szorosabbá füzi az iskolai oktatás során szerzett tudás és a mindennapi élet közötti kapcsolatot. Segít a környezet iránti érdeklődés felkeltésében és felelösségérzet kialakulásában, ami alapja lehet a környezettudatos magatartás formálódásának. Megismerkednek a diákok a biológiai sokféleséggel és annak jelentőségével, mely jó alapot biztosít arra, hogy a 
későbbiekben könnyebben átlássák, milyen következményekkel járhat a nem fenntartható életvitelből következő biológiai sokféleség csökkenése.

\section{Ökoiskolák}

A fenntarthatóságra nevelés egyik hazai programja az Ökoiskola program, melybe a két általunk választott iskola, a Németvölgyi Általános Iskola, illetve a budaörsi 1. sz. Általános Iskola is bekapcsolódott. Az ökoiskolák olyan intézmények, amelyek a fenntarthatóságra nevelést tekintik pedagógiai tevékenységük mozgatójának, így annak törekvései, elvei átszövik az iskolai élet minden területét (vö. Varga, 2003). A hallgatók ezeken a helyszíneken tanítási órák, témanapok, szakkörök, kirándulások és fakultációk tartásán keresztül kapcsolódnak be a munkába. Az évente több alkalommal megrendezésre kerülő témanapok által körüljárt kérdések között szerepelt az „Egészséges életvitel”, a „Föld és az Univerzum”, valamint a „Ritmus, mozgás, körforgás” nevet viselő tematikus egység. Ezeket a hallgatók résztémákra bontva, önállóan vagy páronként, interaktív tevékenységeken keresztül dolgozták fel. A résztémákat alkalmanként 8-8 gyermekcsoporttal, egyenként 20-25 perces foglalkozások keretén belül dolgozták fel a hallgatók, így lehetöségük nyílt gyakorlatban is elmélyíteni módszertani ismereteiket. A „Ritmus, mozgás, körforgás” téma keretén belül feldolgozásra kerülő résztémák többek között az alábbiak voltak:

- a növények, az állatok és az emberek életének ciklusai,

- táplálékhálózatok,

- az erdő életének éves körforgása,

- a napszakok jellemzői.

A következőkben röviden ismertetett helyszíneken való szakmai gyakorlat a hallgatók számára a fenntarthatóságra nevelés terén megvalósuló munkába való betekintést, bekapcsolódás lehetőségét jelentette. Ezeknek a helyszíneknek elengedhetetlen szerepe van a közvetlen, élményeken keresztül szerezhető tapasztalatszerzésben, mely a megismerést játékosabbá, szórakoztatóbbá teszi.

\section{Szemlö-hegyi-barlang}

A Duna-Ipoly Nemzeti Park felügyelete alá tartozó Szemlő-hegyi-barlang a bemutatóhelyeken végzett fenntarthatóságra nevelési tevékenység megismerésére alkalmas helyszín. A gyakorlatok során hallgatóinknak alkalma nyílt gyermekek és felnőttek számára bemutatni a térség védett növény- és állatfajait, az itt létesített interaktív teremben megismertetni a látogatókkal a terület kőzeteit és ásványait, valamint végigkalauzolni óvodás és kisiskolás csoportokat a barlang látogatható részein.

\section{Magyar Természettudományi Múzeum}

Amikor a környezeti neveléssel kapcsolatban a múzeumok használatára hívjuk fel a figyelmet, szem előtt kell tartanunk, hogy a múzeumok olyan sajátos kulturális 
intézmények, melyeket nagyon jól lehet használni a környezeti tevékenység során, hiszen közös célja az iskolával a kultúrához való hozzáférés biztosítása egy új tanulási környezetben. Ezen a helyszínen hallgatóink a múzeumpedagógia néhány szegmensével ismerkedhettek meg, hulladékokból állatfigurákat készítettek gyermekekkel, valamint ők maguk is tervezhettek, és tarthattak foglakozást.

\section{A szakmai gyakorlateredményei és konklúziói}

A gyakorlatok alapvetően pozitív eredménnyel zárultak. Legfontosabb értékekként hallgatóink a következőket emelték ki:

- nőtt a témával kapcsolatos motiváltságuk, magabiztosságuk, felelősségtudatuk, fejlődött kreativitásuk;

- a fenntarthatóság témakörében bővültek ismereteik, ezeket sikeresen tudják majd alkalmazni további életükben, pedagógiai munkájukban;

- olyan változatos pedagógiai módszerek alkalmazására adott lehetőséget, amelyekkel tanulmányaik során csak ritkán van lehetőségük (például projektmódszer, drámapedagógia, kooperatív tanulási technikák stb.)

- valós pedagógiai helyzetekkel, problémákkal találkoztak, így fejlődött döntéshozó képességük, szakmai önállóságuk;

- gyakorló pedagógusként képesek lesznek tevékenyen bekapcsolódni egy intézmény környezeti nevelési programjának tervezésébe;

- megtapasztalhatták, hogyan lehet együttmüködni az egyes intézmények szakembereivel; hogyan kell összeállítani egy egész iskolát megmozgató programot, milyen nehézségekkel kell számolni, mikre kell fokozottan figyelni;

- a szakmai gyakorlat tudományos diákköri, illetve szakdolgozati munka keretében folytatott kutatás kiindulási alapjául szolgál.

A hallgatók visszajelzései és szakmai érdeklődése, a fogadó intézmény kérése, valamint az aktuális hallgatói létszámalapján a 2011-ben kijelölt, illetve választott helyszíneket részben módosítottuk, bővítettük. A 2013/2014-es tanév második félévében együttműködés indult tanszékünk és a konstruktív pedagógiai módszerekkel dolgozó Deák Diák Általános Iskola között, megismerhettük a Pangea Egyesület müködését, valamint a sajátos nevelési igényü gyermekek fenntarthatóságra nevelési gyakorlatába is bekapcsolódhatunk a Vakok Állami Intézetének segítségével.

Bízunk abban, hogy a külső helyszíneken zajló önkéntes munka ténylegesen hozzájárult hallgatóink környezettudatos attitüdjének formálásához, egy a környezettel harmóniában lévő életstratégia kialakításához, s ahhoz, hogy fejlődtek azon kompetenciáik, melyek segítségével képessé válnak a kisiskoláskorú gyermekek környezettudatos magatartásának fejlesztésére;

Ez a távlati cél arra ösztönöz bennünket, hogy megadjuk a lehetőséget valamennyi végzős hallgatónknak, szaktól függetlenül arra, hogy felsőoktatási tanulmányai során elsajátíthassa a fenntarthatóságért felelős magatartás 
kialakításához szükséges legfontosabb ismereteket, hozzáállást és cselekvési kompetenciákat.

\section{Irodalom}

Beagle projekt oldala http://mkne.hu/projektek.php?projekt=10

Cade, Adam, Bowden, Rob (2011): Youth Xchange. Climate Change and Lifestyles Guidebook. UNEP-UNESCO, Paris. http://www.unep.org/pdf/YXC_CC_Single_Pages_230911.pdf

Carbon Detectives hivatalos oldala www.carbondetectives.hu

Carbon Detectives projekt oldala http://mkne.hu/projektek.php?projekt=12

Füzné Koszó Mária (2012): A BEAGLE Program. Fákat vallató fiatalok. Természetbúvár 65., 40-41.

Füzné Koszó Mária (2013): Out of Classroom Project for Biodiversity education in Hungary: A Case Study. US-China Education Review B, 3. 11., 870-881.

Lohri, Franz, Schwyter, Astrid (2004): Találkozzunk az erdőben! Erdőpedagógia. Ökofórum Alapítvány, Budapest.

Varga Attila (2003): A környezeti nevelés a magyar közoktatásban - az ökoiskolák szemszögéböl. Új pedagógiai Szemle, 53. 3., 55-67.

Vásárhelyi Judit (2010, szerk.): Nemzeti Környezeti Nevelési Stratégia. Magyar Környezeti Nevelési Egyesület, Budapest.

Vastagné Bauer Zita, Pákozdi Erika, Bihariné dr. Krekó Ilona és M. Darvay Sarolta (2011): „Az én fám” projekt. In: Kováts Németh Mária (szerk.): Együtt a környezetért. Palatia Nyomda és Kiadó Kft., Györ, 321-327.

Vida Gábor (2001): Helyünk a bioszférában. Typotex Kiadó, Budapest. 